\title{
PREFACE TO THE SPECIAL ISSUE OF FOOD SCIENCE CONFERENCE 2014 - CORVINUS UNIVERSITY OF BUDAPEST. DARÁNYI IGNAC PROGRAM, A COMPREHENSIVE FRAMEWORK OF FOOD INDUSTRIAL DEVELOPMENT IN HUNGARY
}

The Hungarian government has laid down the most important strategic goals of agricultural development, based on the Programme of National Cooperation in the National Ruraldevelopment Strategy. The Darányi Ignác Program determines the most important goals of rural development: focusing on sustainability, the economically and ecologically sustainable food productions, building on traditions and optimal utilisation of natural endowments.

The Darányi Ignác Program has been named after Ignác Darányi (1849-1927), a leading figure of the Hungarian agricultural policy formation in the last decade of the 19th century and at the beginning of the 20th century. He had been fulfilling the position of Minister of Agriculture for more than 12 years. Under his guidance, considerable development has been achieved in the field of agricultural regulation and modernisation. "Hungary was always at its strongest when its agriculture was flourishing" determines the Darányi Ignác Program, highlighting the importance of planned and harmonised, system-based as well as concentrated utilisation of sources from the European Union and from Hungarian national resources. One of the most important goals of the Darányi Ignác Program is the development of food industry. The most important steps in this direction are the improvement of image of Hungarian agrofood products, increasing the level of consciousness of consumers, and the upgrading of competitiveness of Hungarian agricultural products by increasing their value-added content.

The Faculty of Food Science at Corvinus University of Budapest is a leading institution of Hungarian food engineering education. Our faculty has been playing a determining role in the development of scientific and human resource base of Hungarian food production. Food engineer generations, who have obtained their qualification at our faculty, fulfil responsible positions in food production, trade, and public administration. It is an old tradition at our Faculty, that we regularly organise scientific conferences with the purpose of proliferating our scientific results, as well as creating of a broad platform for academic discussion and interpersonal, direct communication. In this year we summarise our results, joining directly to the scientific foundations of the Darányi Ignác Program.

In this special issue of the Acta Alimentaria, the best papers of the international Food Science Conference 2014 organized at the Faculty of Food Science are published.

Cs. Mohácsi-Farkas and Z. LAKNER Members of the Organizing Committee 